\title{
PENGARUH DOSIS PROTEIN DALAM PAKAN TERHADAP PERKEMBANGAN GONAD DAN PEMIJAHAN INDUK TERIPANG PASIR (Holothuria scabra)
}

\author{
Made Suastika*), Sari Budi Moria") dan Darmansyah")
}

\begin{abstract}
ABSTRAK
Teripang merupakan komoditas ekonomis penting dan mudah dipasarkan sebagai komoditas ekspor, namun hingga saat ini ekspornya masih tergantung dari hasil tangkapan di alam. Usaha pembudidayaan teripang masih mempunyai kendala dalam penyediaan benih. Dalam rangka menunjang perbenihan teripang telah dilakukan penelitian untuk mengetahui dosis protein yang tepat dalam pemberian pakan yang dapat mempercepat proses pematangan gonad teripang pasir. Pada penelitian ini induk teripang diberi pakan percobaan dengan dosis protein yang berbeda yaitu: $\mathrm{A}=10 \%, \mathrm{~B}=20 \%, \mathrm{C}=30 \%$, dan sebagai kontrol (D) menggunakan pakan hanya berupa tepung klekap (protein 7,4\%). Pakan diberikan $\%$ dari bobot biomassa. Percobaan menggunakan rancangan acak lengkap dan setiap perlakuan terdiri atas tiga kali ulangan. Induk teripang dipelihara dalam bak serat gelas yang disekat menjadi empat bagian, dan penelitian berlangsung selama enam bulan. Setiap 45 hari dilakukan pengamatan tingkat kematangan gonad dan pada akhir penelitian dihitung indeks kematangan gonad, protein efisiensi rasio serta kandungan sel telur dan sperma di dalam gonad.
\end{abstract}

Hasil penelitian menunjukkan bahwa dosis protein dalam pakan memberikan pengaruh yang berbeda nyata terhadap indeks kematangan gonad (IKG) dan protein efisiensi rasio. Perlakuan $\mathrm{C}$ (dosis protein 30\%) memberikan hasil terbaik dalam mempercepat peroses pematangan gonad, dan dalam jumlah sel telur dan sperma di dalam gonad untuk betina IKG $=24,0 \%$ dan sel telur $=80,9 \times 10^{6} /$ gonad, sedangkan untuk jantan $\mathrm{IKG}=20,2 \%$ dan sel sperma $=70,2 \times 10^{6} /$ gonad. Hingga akhir penelitian pemijahan tidak terjadi karena pematangan gonad jantan dan betina tidak bersamaan waktunya.

\begin{abstract}
Effect of protein levels in diet on gonadal development and spawning of sea cucumber (Holothuria scabra) broodstock. By: Made Suastika, Sari Budi Moria and Darmansyah.
\end{abstract}

Sea cucumber is an exportable commodity, and most of the exported animal are caught from natural source. Efforts to culture it have been made, but much depends on its seeds supply. The purpose of this experiment was to examine the effect of protein levels in the diet on the gonad maturation of sea cucumber Holothuria scabra. Formulated feed with different levels of protein namely $10 \% ; 20 \%$; and $30 \%$ were used and as control, lablab meal with protein content of 7,4\% was used. Feed was given at $2 \%$ of biomass weight. Sea cucumber were kept for six months in fiber glass tanks with a capacity of 500 litre divided into four chambers. Every 45 days, gonad maturation stage was identified and at the end of the experiment, gonad somatic index (GSI), protein efficiency ratio $(P E R)$ and the number of ovum or sperm in the gonad were arised.

The result showed that dietary protein levels significantly affected gonad somatic index (GSI) and protein efficiency ratio (PER). Protein level of $30 \%$ was the best in terms of increasing gonad maturation rate. Treatment with $30 \%$ protein revealed that for female the GSI was $24 \%$ and total ovum was $80,9 \times 10^{6}$ cell/gonad, while for the male the GSI was 20,2\% and total sperm was $70,2 x$ $10^{6} \mathrm{cell} /$ gonad. Up to the end expriment there was no spawning observed due to the different time of male and female gonad maturation.

KEYWORDS: gonad development, gonad somatic index, protein efficiency ratio.

\footnotetext{
Peneliti pada Loka Penelitian Perikanan Pantai Gondol, Bali
} 


\section{PENDAHULUAN}

Upaya pengembangan perikanan secara nasional dan terpadu khususnya jenis komoditas perikanan komersial yang mencakup ikan dan nonikan dikembangkan sebagai komoditas ekspor nonmigas. Satu di antara jenis biota laut yang cukup potensial untuk dikembangkan adalah teripang, karena selain sebagai sumber protein yang cukup tinggi $(50-60 \%)$ juga digunakan dalam industri obat-obatan dan kosmetik di beberapa negara maju (Walford dalam Saenong 1988; Hall \& Dingle dalam Bakus (1970). Di alam teripang memanfaatkan makanan dari partikel substrat yang ada di dasar air. Makanan teripang terdiri atas organisme-organisme kecil seperti: detritus, protozoa, diatom, algae, kopepoda, ostrakoda, dan rumput laut; di samping itu juga foraminifera, radiolaria, dan partikel partikel pasir atau hancuran karang dan cangkang cangkang hewan (Bakus, 1970; Hyman, 1965). Menurut Widodo (1984) pakan teripang di alam, 80\% merupakan komponen yang paling banyak dimakan yaitu partikel pasir dan $20 \%$ protein dari organisme kecil. Karena di alam pasokan protein dari pakan didapatkan hanya sedikit menyebabkan pertumbuhannya lambat termasuk perkembangan organ reproduksi khususnya pematangan gonad. Pematangan gonad juga sangat dipengaruhi oleh berbagai faktor lingkungan terutama iklim (Boolootian dalam Cameron \& Fankboner, 1986). Sedangkan pengaruh suhu dan cuaca hujan secara tidak langsung berpengaruh terhadap tersedianya makanan (Bligh et al., 1976).

Upaya pemberian pakan dalam pembesaran teripang dengan metode kurung tancap (benih berasal dari alam) telah dilaksanakan dengan pemberian pakan rumput laut jenis Gracilaria dan Eucheuma memberikan sintasan yang tinggi (Rachmansyah et al., 1992). Jika mengandalkan keberadaan benih yang berasal dari alam dengan jumlah yang terbatas dan tergantung musim, ketersedian benih belum tentu dapat dijamin kontinuitasnya. Penelitian teripang pasir pada bak secara terkontrol sudah dilaksanakan di Loka Penelitian Perikanan Pantai Gondol, Bali. Dalam mendukung perbaikan organ reproduksi khususnya mengenai pematangan gonad teripang di samping media pemeliharaan yang tepat, kualitas dan kuantitas pakan mutlak diperlukan.
Satu di antara kendala yang dihadapi dalam pemeliharaan teripang di bak pemeliharaan secara terkontrol adalah belum diperolehnya komposisi pakan maupun jenis pakan yang tepat. Protein merupakan zat pakan yang sangat diperlukan ikan bagi pertumbuhan, kadar protein pakan dapat mempengaruhi tinggi rendahnya pertumbuhan ikan (Khans et al., 1993, Mokoginta et al., 1995). Dalam pengamatan Jufri et al. (1994) pemberian pakan campuran tepung klekap dan tepung kedelai kandungan protein $7,41 \%$ dan $40,9 \%$ sebanyak $2 \%$ bobot teripang pasir memberikan tingkat kematangan gonad yang tinggi. Walaupun demikian penelitian pakan induk teripang pasir di bak pemeliharaan secara terkontrol khususnya mengenai penggunaan protein yang tepat untuk mempercepat proses pematangan gonad dan pemijahan teripang pasir masih perlu dilanjutkan. Berdasarkan latar belakang permasalahan tersebut, maka dilakukan penelitian dengan tujuan mendapatkan dosis protein dalam pakan yang tepat untuk memacu pematangan gonad dan pemijahan teripang pasir.

\section{BAHAN DAN METODE}

Penelitian ini dilaksanakan di Laboratorium Loka Penelitian Perikanan Pantai Gondol. Dalam penelitian ini digunakan induk teripang dengan kisaran bobot 100-300 gram/ekor diperoleh dari hasil tangkapan nelayan di alam. Wadah pemeliharaan yang digunakan berupa bak serat gelas dengan ukuran 500 liter sebanyak 12 buah yang dilengkapi aerasi dan pasir sebagai substrat. Masing-masing bak disekat menjadi empat bagian dengan bahan waring, kemudian pada setiap sekat dipelihara sepasang teripang yaitu teripang jantan dan betina. Pakan buatan dengan kandungan dosis protein yang berbeda sebanyak $2 \%$ per bobot biomassa setiap hari. Induk teripang yang digunakan lebih dahulu dikosongkan organ dalamnya dengan cara stripping setelah ikan disuntik dengan larutan KCL 0,5 mol sebanyak $3 \mathrm{~mL}$. Dengan cara tersebut usus akan tumbuh terbentuk kembali setelah 30 hari dan gonad setelah 45 hari (Jufri et al., 1994). Induk teripang diberi pakan satu kali sehari. Sisa pakan disipon serta air diganti sebanyak $400 \%$ per hari, dalam pemeliharaan dengan sistem air mengalir. Sebagai bahan acuan untuk menentukan perkembangan gonad dan tingkat kematangan gonad digunakan pedoman hasil penelitian menurut Liu \& Huiling (1996). 
Disain penelitian menggunakan rancangan acak lengkap dengan empat perlakuan dan tiga kali ulangan. Perlakuan yang digunakan adalah pemberian pakan dengan dosis protein yang berbeda yaitu: $A=10 \%, B=20 \%, C=30 \%$, dan $D=7,4 \%$ (hanya tepung klekap) sebagai kontrol. Komposisi pakan yang dibuat dengan dosis protein yang berbeda dan analisis proksimat disajikan pada Tabel 1 dan 2. Peubah yang diamati adalah: perkembangan gonad, indeks kematangan gonad (IKG), jumlah sel telur dan sperma yang terkandung dalam gonad yang belum memijah (tingkat kematangan III dan IV). Pengamatan gonad dilakukan setiap 45 hari dengan membedah sepasang teripang dari setiap perlakuan dan ulangan. Pada saat pengamatan jika ditemukan gonad yang sudah matang tingkat III dan IV, langsung dilakukan penghitungan jumlah sperma dan ovum di dalam gonad. Untuk mengetahui jumlah sel telur dan sperma di dalam gonad dilakukan pengamatan dengan mikroskop setelah diencerkan dengan larutan $\mathrm{Ca}^{3+}$, dan pada akhir penelitian dapat dihitung efisiensi pakan yang dibutuhkan selama penelitian.

Tabel 1. Komposisi pakan dengan dosis protein berbeda(\%).

Table 1. Composition of basal diet with different levels of protein (\%).

\begin{tabular}{|c|c|c|c|c|}
\hline \multirow{2}{*}{$\begin{array}{l}\text { Perlakuan } \\
\text { Treatment }\end{array}$} & \multicolumn{4}{|c|}{ Pakan (Feed) } \\
\hline & $\mathrm{A}$ & $\mathbf{B}$ & $\mathbf{C}$ & $\mathbf{D}$ \\
\hline \multicolumn{5}{|l|}{$\begin{array}{l}\text { Bahan pakan } \\
\text { Ingredient }\end{array}$} \\
\hline Tepung klekap (Lablab meal) & 48.97 & 43.78 & 38.60 & 100 \\
\hline Tepung ikan (Fish meal) & 13.79 & 27.60 & 41.40 & - \\
\hline Campuran vitamin (Vitamin mix) & 1.0 & 1.0 & 1.0 & - \\
\hline Campuran mineral (Mineral mix) & 3.0 & 3.0 & 3.0 & - \\
\hline Tepung kanji (Tapioca meal) & 25.2 & 17.6 & 10 & $\cdot$ \\
\hline Tepung beras (Rice meal) & 6.0 & 6.0 & 6.0 & - \\
\hline Minyak ikan (Fish oil) & 2.04 & 1.02 & $\cdot$ & - \\
\hline Total & 100 & 100 & 100 & 100 \\
\hline
\end{tabular}

Tabel 2. Komposisi proksimat pakan yang digunakan dalam percobaan.

Table 2. Proximate composition of feed used in the experiment.

\begin{tabular}{lrrrrr}
\hline \multirow{2}{*}{$\begin{array}{l}\text { Komposisi(Composition) } \\
\text { \% }\end{array}$} & \multicolumn{5}{c}{ Pakan (Feed) } \\
\cline { 3 - 6 } & & A & B & C & D \\
\hline Protein (Crude protein) & $\%$ & 11.56 & 22.66 & 29.46 & 7.41 \\
Lemak (Crude fat) & $\%$ & 1.74 & 3.32 & 3.16 & 0.04 \\
Abu (Ash) & $\%$ & 42.21 & 40.62 & 43.07 & 62.74 \\
Air (Moisture) & $\%$ & 0.94 & 3.23 & 3.01 & 5.36 \\
Energi (Energy) & kcal/g & 130.01 & 164.1 & 180.55 & 83.33 \\
\hline $\begin{array}{l}A=10 \% \text { protein } \\
B=20 \% \text { protein }\end{array}$ & $\begin{array}{l}C=30^{\circ} \% \text { protein } \\
D=7.4 \% \text { protein (control) }\end{array}$ & & & &
\end{tabular}


Untuk penentuan IKG digunakan rumus Effendie (1979). Sedangkan perhitungan protein eficiency ratio (PER) menurut Watanabe (1985) sebagai berikut:

$$
\begin{aligned}
& \text { IKG }=\frac{\text { Bobot gonad }}{\text { Bobot bersih }+ \text { Bobot organ dalam }} \times 100 \% \\
& \text { PER }=\frac{\text { Peningkatan bobot teripang hidup }}{\text { Bobot protein pakan yang diberikan }}
\end{aligned}
$$

\section{HASIL DAN PEMBAHASAN}

\section{Pengaruh Pakan terhadap Gonad}

\section{a. Perkembangan gonad}

Perkembangan gonad teripang setelah diberi pakan dengan dosis protein yang berbeda dengan energi yang berbeda pula, disajikan pada Tabel 3.

Hasil pengamatan memperlihatkan semua gonad jantan dan betina berkembang akan tetapi waktu yang diperlukan untuk mencapai perubahan tingkat dari masing-masing perlakuan berbeda. Tahel 3 memperlihatkan bahwa untuk mencapai gonad betina tingkat IV pada pcrlakuan $A$ dan $B$ menbutuhkan waktu 135 hari, tetapi pada perlakuan ( hanya membutuhkan waktu 90) hari. Untuk jantan, gonad matang tingkat IV dalam waktu 180 hari terjadi pada perlakuan $B$ dan C. sedangkan pada kontrol, pada waktu yang sama baru dapat dicapai kematangan tingkat II sementara perlakuan A baru mencapai tingkat III. Ini berarti dengan pakan berkadar protein rendah $(10 \%)$ atau hanya berupa tepung klekap $(<10 \%)$ pematangan gonad teripang pasir berkembang sangat lambat. Pada perlakuan $C$ sebenarnya gonad betina telah matang tingkat IV pada 90 hari atau tiga bulan, akan tetapi pada saat itu pemijahan belum dapat berlangsung karena gonad jantan belum ada yang matang tingkat IV. Karena sel telur keluar tanpa diikuti sel sperma maka terjadilah pemijahan sebagian. Pertumbuhan bohot gonad rata rata pada masing. masing perlakuan dari pemberian dosis protein dalam pakan disajikan pada Gambar 1 .

Dari gambar tersebut dapat dilihat bahwa bobot rata-rata gonad teripang betina pada perlakuan $\mathrm{C}$ (protein $30 \%$ ) memberikan pertumbuhan gonad yang lebih baik, kemudian disusul dengan perlakuan $B$ dan perlakuan $A$, sedangkan pada induk jantan bobot rata-rata gonad pada perlakuan A lebih besar daripada perlakuan $B$. Bertambahnya bobot rata-rata pada perlakuan $\mathrm{A}$ ini disebabkan karena pada gonad jantan secara visual terdapat rumbai gonad pada tingkat II dan III lebih banyak dibandingkan dengan tingkat IV menyebabkan bobot gonad lebih besar.

Tabel 3. Perkembangan gonad teripang selama penelitian.

Table 3. Conad development of sea cucumber during the experiment.

Tingkat kematangan gonad

\begin{tabular}{|c|c|c|c|c|c|c|c|c|}
\hline \multirow[t]{2}{*}{$\begin{array}{r}\text { Pakan } \\
\text { (Feed) }\end{array}$} & \multicolumn{2}{|c|}{$\begin{array}{c}15 \\
\text { havi (days) } \\
\end{array}$} & \multicolumn{2}{|c|}{$\begin{array}{c}90 \\
\text { hari (days) }\end{array}$} & \multicolumn{2}{|c|}{$\begin{array}{c}135 \\
\text { hauri (days) }\end{array}$} & \multicolumn{2}{|c|}{$\begin{array}{c}180 \\
\text { hari (days) }\end{array}$} \\
\hline & q & $0^{*}$ & $q$ & $\sigma^{x}$ & 9 & $\sigma^{*}$ & 운 & $\sigma^{*}$ \\
\hline A & I & I & III & 11 & IV $\phi$ & II & I & III \\
\hline B & II & II & JII & II & IV $\phi$ & III & II & IV \\
\hline C & III & I & IV $\phi$ & II & I & III & III & IV \\
\hline D & I & I & I & 1 & I & I & II & II \\
\hline
\end{tabular}

Gonad maturation stage 


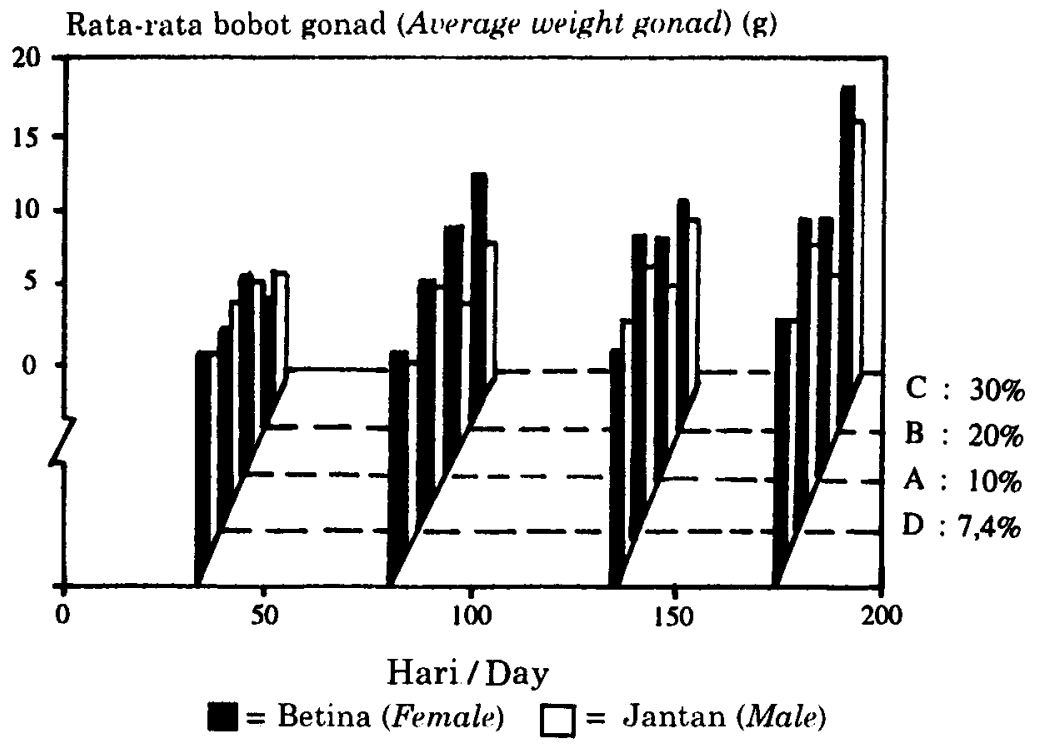

Gambar 1. Pertumbuhan bobot rata-rata gonad teripang.

Figure 1. Average weight growth of sea cucumber gonad.

\section{b. Indeks kematangan gonad}

Dari berbagai tingkat kematangan gonad yang diamati secara visual melalui pembedahan, keragaman karateristik gonad secara kuantitatif dapat dihitung berdasarkan rumus Effendie (1979). Indeks kematangan gonad teripang pasir pada masing-masing perlakuan disajikan pada Tabel 4.

Tabel 4 menunjukkan bahwa dosis protein dalam pakan memberikan pengaruh yang berbeda sangat nyata terhadap indeks kematangan gonad teripang pasir. Pada perlakuan $\mathrm{C}$ pemberi- an dosis protein $30 \%$ dengan kandungan energi 180,55 kilokalori/gram memberikan indeks kematangan gonad yang paling tinggi baik pada teripang pasir betina maupun jantan. Pada induk betina terlihat bahwa semakin rendah dosis protein yang diberikan indeks kematangan gonadnya semakin kecil. Indeks kematangan gonad induk betina dengan jantan berbeda, pada induk jantan terdapat perbedaan tingkat kematangan gonad antara perlakuan A dan B yang disebabkan oleh perbedaan bobot rata-rata gonad A dengan gonad $B$ (Gambar 1) sehingga menyebabkan nilai IKG A lebih besar dibandingkan dengan IKG B.

Tabel 4. Persentase indeks kematangan gonad teripang pasir dengan dosis protein berbeda dalam pakan.

Table 4. Percentage of GSI of sea cucumber feed with different levels of protein.

\begin{tabular}{|c|c|c|}
\hline \multirow[t]{2}{*}{$\begin{array}{l}\text { Perlakuan } \\
\text { Treatment }\end{array}$} & \multicolumn{2}{|c|}{$\begin{array}{c}\text { Indeks kematangan gonad (IKG) } \\
\text { Gonad somatic index (GSI) }\end{array}$} \\
\hline & Betina (Female) & Jantan (Male) \\
\hline A & $11.4^{b}$ & $9.8^{b}$ \\
\hline B & $11.8^{\mathrm{b}}$ & $8.73^{a}$ \\
\hline $\mathrm{C}$ & $24.0^{\mathrm{c}}$ & $20.2^{\mathrm{c}}$ \\
\hline $\mathrm{D}$ & $6.4^{\mathrm{a}}$ & $5.73^{d}$ \\
\hline $\begin{array}{l}A=10 \% \text { protein } \\
B=20 \% \text { protein }\end{array}$ & $\begin{array}{l}30 \% \text { protein } \\
7,4 \% \text { protein (control) }\end{array}$ & \\
\hline
\end{tabular}




\section{c) Jumlah sel telur dan sperma}

Jumlah sel trlur dan sperma yang terkandung di dalam gonad dari hasil pengamatan disajikan pada 'Tabel 5. Dari Tabel 5 terlihat bahwa semakin tinggi dosis protein semakin tinggi pula jumlah sel telur dan sperma yang terkandung di dalam gonad. Jumlah telur dan sperma dari perlakuan kontrol tidak dapat diamati karena hingga penelitian diakhiri gonad belum mencapai kematangan tingkat III.

\section{d) Rasio efisiensi protein}

Perbandingan jumlah pakan yang dibutuhkan untuk mendapatkan pertumbuhan vang lebih baik selama pemelihaman teripang pasir disajikan pada Tabel 6. Tabel $(\mathrm{i}$ memperlihatkan bohot tubuh rata-rata awal dan akhir penelitian, jumlah pakan yang dibutulkan serta perhitung- an protein efisiensi ratio (PER) menurut Watanabe (1995).

Dari hasil perhitungan uji statistik rasio perbandingan protein pakan yang dibutuhkan untuk pertumbuhan bobot tubuh teripang, antara penambahan protein dibandingkan dengan pakan klekap sebagai kontrol didapatkan adanya perbedaan yang nyata $(P>0,05)$. Penambahan protein yang lebih besar dari pakan klekap $(7,4 \%)$ memberikan pertumbuhan bobot tubuh yang lebih baik. Jika dilihat penambahan protein pada pakan $10 \%, 20 \%$ dan $30 \%$ tidak memberikan perbedaan dalam pertumbuhan bobot tubuh, akan tetapi di antara penambahan protein pakan $10 \%$, $20 \%$ dan $30 \%$. penambahan protein $30 \%$ lebih efisien digunakan karena di samping pertumbuh. an bobot tubuhnya lebih baik juga indeks kematangan gonadnya lebih besar dan waktu yang dibutuhkan lebih cepat untuk mendapatkan induk teripang yang matang gonad tingkat IV.

Tabel 5. Jumlih sel telur dan sperma dalam gonad( $\left.X 10^{6} \mathrm{sel}\right)$.

Table.5. Total number of oum and sperm in the gonad $X 10^{6}$ (ell).

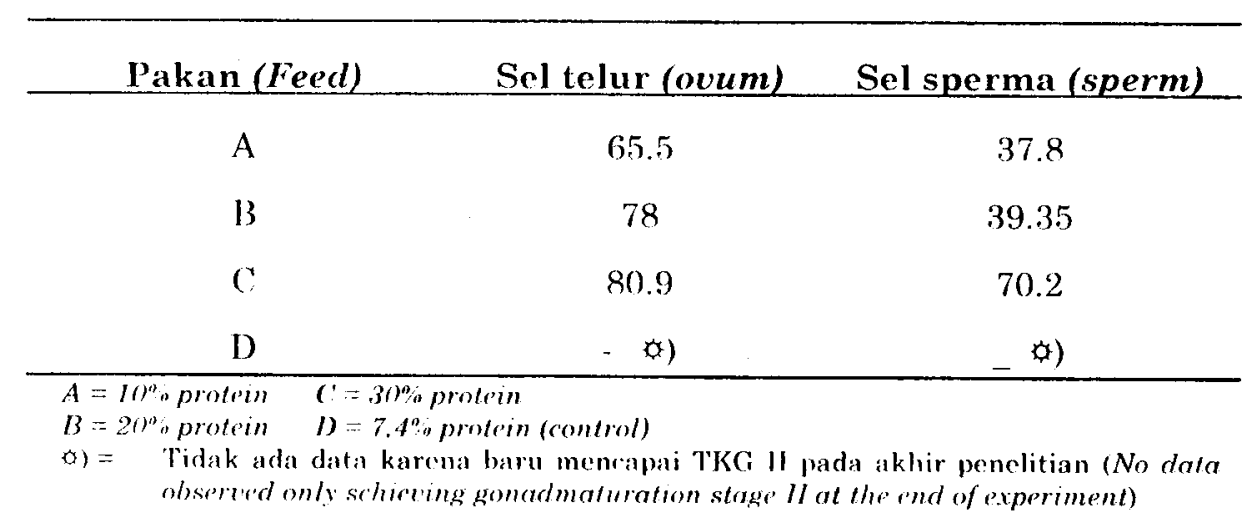

Tabel 6. Bobot tubuh rata rata teripang dan rasio efisiensi protein selama pengamatan. Table 6. Average sea cucumber weight and protein eficiney ratio during the experiment.

\begin{tabular}{|c|c|c|c|c|c|c|c|}
\hline \multirow[t]{2}{*}{$\begin{array}{l}\text { Perlakuan } \\
\text { Treatment }\end{array}$} & \multirow[t]{2}{*}{$\begin{array}{c}\text { Total pakan } \\
\text { Tolal feed }\end{array}$} & \multicolumn{2}{|c|}{$\begin{array}{l}\text { Bobot awal } \\
\text { Initial weight }\end{array}$} & \multicolumn{2}{|c|}{$\begin{array}{l}\text { Bobot alhir } \\
\text { Final weight }\end{array}$} & \multicolumn{2}{|c|}{$\begin{array}{l}\text { Rasio efisiensi protein } \\
\text { Protein eficiency ratio }\end{array}$} \\
\hline & & $\sigma^{n}$ & $i$ & 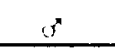 & $y$ & 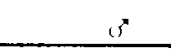 & 7 \\
\hline A & 55.37 & 149.6 & 134.5 & 176 & 173.6 & 0.186 & $0.735^{b}$ \\
\hline$B$ & 48.4 & $166 ; .5$ & 105.73 & 183.9 & 181.2 & 0.496 & $0.788^{1}$ \\
\hline c & 60.9 & 119.8 & 129.7 & 184.5 & 179.5 & 0.652 & $0.852^{b}$ \\
\hline D) & 39 & 1333.1 & 130.6 & 139.2 & $1: 34.4$ & 0.158 & $0.078^{i}$ \\
\hline $\begin{array}{l}A=1 m^{\prime \prime \prime} \\
B=2 m^{\prime \prime}\end{array}$ & $\begin{array}{l}r= \\
b=\end{array}$ & 1 & & & & & \\
\hline
\end{tabular}


Tabel 7. Kisaran parameter kualitas air selama pengamatan.

Table 7. $\quad$ Range of water quality parameters during the experiment.

\begin{tabular}{lcc}
\hline \multicolumn{1}{c}{$\begin{array}{c}\text { Peubah kualitas air } \\
\text { Water quality parameter }\end{array}$} & $\begin{array}{c}\text { Kisaran nilai } \\
\text { Range of value }\end{array}$ \\
\hline Suhu air (Water temperature) & $\left(0^{\circ} \mathrm{C}\right.$ & $26.6-27.3$ \\
$\mathrm{pH}$ & & $6.8-8.0$ \\
Salinitas (Salinity) & $(\mathrm{ppt})$ & $30.0-34.0$ \\
Amonia ( $\mathrm{NH}_{3} /$ Ammonia) & $(\mathrm{mg} / \mathrm{L})$ & $0.06-0.017$ \\
Oksigen terlarut (Dissolved oxygen) & $(\mathrm{mg} / \mathrm{L})$ & $7.57-7.98$ \\
$\mathrm{NO}_{2}-\mathrm{N}$ (Nitrite) & $(\mathrm{mg} / \mathrm{L})$ & $0.075-0.269$ \\
$\mathrm{NO}_{3}-\mathrm{N}$ (Nitrate) & $(\mathrm{mg} / \mathrm{L})$ & $0.010-0.019$ \\
\hline
\end{tabular}

\section{Kualitas Air}

Pemantauan terhadap beberapa kualitas air disajikan pada Tabel 7 yang meliputi suhu, $\mathrm{pH}$, oksigen terlarut, nitrit; nitrat dan salinitas yang ternyata masih layak dalam pemeliharaan.

Menurut Jufri et al. (1994) kandungan oksigen $=4,80-6,72$, nitrit $=0,009-0,057$, nitrat $=0,10-0,424$ suhu $=25,5 \cdot 30^{\circ} \mathrm{C}$ masih berada pada kisaran yang layak dalam menunjang perkembangan gonad.

\section{KESIMPULAN}

Penambahan protein $10 \%$ hingga $20 \%$ dapat meningkatkan kematangan gonad betina hingga tingkat III pada hari ke-90, sedangkan pada penambahan protein $30 \%$, kematangan gonad betina tingkat III telah tercapai pada pemeliharaan 45 hari. Sementara itu, untuk gonad jantan pada hari ke-90 kematangan tingkat II dicapai bila menggunakan pakan dengan protein berkadar di atas $10 \%$.

Adapun pada kontrol, tanpa penambahan protein kematangan gonad jantan maupun betina pada tingkat II baru tercapai pada hari ke-180. Penambahan protein pada pakan juga memberikan jumlah sel telur dan sperma yang lebih besar.

\section{DAFTAR PUSTAKA}

Bakus, G.J. 1970. The biology and ecology of tropical holothurian. Academic Press, London. 121-139.
Bligh, J., J.L. Cludsly and A.G. Mc Donald. 1976. Enviromental physiology of animal, Blackwell Scientific Publication, Oxford London. Edenburgh. Melbourne. 134-146.

Cameron, J. L. and P.V. Fankboner. 1986. Reproductive biology of the commercial sea cucumber Parastichopus californicus (Stimpson). Can. J. Zool. 64(1):168.1776

Effendie, M.I. 1979. Metode biologi perikanan. Yayasan Dewi Sri Bogor 112:492.

Hyman, L.H. 1965. The invertebrates. The Echinoderms Vol. IV. Mc Graw-Hill Book Company Co. Inc. New York 763 hal.

Jufri, D. Makatutu dan I. Rusdi. 1994. Uji pendahuluan pemberian pakan tambahan terhadap kemampuan regenerasi organ dalam teripang pasir Holothuria scabra. Sub Balai Penelitian Perikanan Pantai Gondol (unpublished).

Khans, M.S., K.J. Ang, M.A. Ambak, and C.R. Saat. 1993. Optimum protein requirement of a Malaysian freshwater catfish (Mystus nemurus). Aquaculture.112:227-235.

Liu, Y.H. and S. Huiling. 1996 . Training manual on breeding and culture of scallop and sea cucumber. Qingdao China, Yellow Sea Fisheries Research Institute Chinese Academy of Fhiseries. United Nation Educational Scientific Cultural Organization: 10-11.

Mokoginta. I., M.A. Suprayudi dan M. Setiawati.1995. Kebutuhan optimum protein dan energi pakan benih ikan gurame (Osphronemus gouramy Lac.) . Jurnal Penelitian Perikanan Indonesia 1. 3: 1 82-93. 
Rachmansyah, M.I. Madeali, A.M. Tangko, S. Tonnek. 1992. Polikultur teripang. Holothuria scabra dan rumput laut, Eucheuma sp. di Teluk Parepare Sulawesi Selatan. Jurnal Penelitian Budidaya pantai Vol.8. 4:63-67.

Saenong, M. 1988. Pengaruh padat penebaran terhadap laju pertumbuhan dan produksi teripang bangkuli (Holothuria scabra Jaeger) di muara Sungai Tallo Kotamadya Ujung Pandang. Tesis
Jurusan Perikanan, Fakultas Perikanan Universitas Hasanudin Ujung Pandang. 69 hal.

Widodo, R. 1984. Studi beberapa aspek biologi dan ekologi teripang (Holothuria sp.) beserta analisa protein di perairan terumbu karang Pulau Pari. Skripsi Institut Pertanian Bogor, Fakultas Perikanan. 37-48.

Watanabe. T. 1985. Fish nutrition and mariculture. JICA Text Book The General Aquaculture Course. 16 . 